\title{
PERFORMANCE MEASUREMENT IN LEAN PRODUCTION SYSTEMS: AN EXPLORATION ON REQUIREMENTS AND TAXONOMIES
}

\author{
Karina B. Barth ${ }^{1}$, Carlos T. Formoso ${ }^{2}$ and Marcus P. Sterzi ${ }^{3}$
}

\begin{abstract}
Performance measurement plays an important role in project and business management, as it focuses on the most important aspects of the business, provides real data and guides actions for improvement. It also provides support for the implementation of some Lean Production principles, such as reducing the share of non-value-adding activities (waste), increasing process transparency, building continuous improvement into the process, and benchmarking. Despite its importance, very little has been reported on the development of PM systems that are effective for assessing the impact of lean implementation. In addition, there is a lack of studies on how Lean companies (or projects) use indicators and to what extent these reflect the result of actions that have been undertaken. Therefore, this paper presents preliminary results of a research study that aims to propose a set of requirements for Performance Measurement (PM) Systems from a lean production perspective, and a taxonomy of metrics for lean production systems. It discusses the scope of the performance metrics adopted by five companies from South America involved in the implementation of Lean Production Systems. The scope of this investigation is limited to construction projects as production systems, rather than PM at the level of construction organizations.
\end{abstract}

\section{KEYWORDS}

Performance measurement, lean construction, production management, continuous improvement, kaizen.

\section{INTRODUCTION}

Performance measurement (PM) is a theme that has received much attention in the literature since the Nineties, both in the field of Operations Management (Neely et al. 1997) and in Construction Management. Regarding the construction industry, several contributions can be found in the literature, including conceptual approaches (Kagioglou et al. 2001),

\footnotetext{
${ }^{1} \mathrm{PhD}$ Candidate, Building Innovation Research Unit - NORIE, Federal University of Rio Grande do Sul, Brazil, kbertotto@gmail.com

${ }^{2}$ Professor, Building Innovation Research Unit - NORIE, Federal University of Rio Grande do Sul, Brazil, formoso@ufrgs.br

${ }^{3}$ MSc, Building Innovation Research Unit - NORIE, Federal University of Rio Grande do Sul, Brazil. Consultant and Managing Partner at LD Consulting, marcus@ldconsulting.com.br
} 
guidelines for assessing PM systems (Costa and Formoso 2004); implementation models (Love and Holt 2000); comparisons between metrics adopted by different companies (Costa et al. 2006); and PM in specific sectors or processes (Robinson et al. 2005). Moreover, there has been several initiatives promoted by industrial organizations that have proposed keyperformance indicators or benchmarking clubs (Costa et al. 2006). The design of a PM system involves more than the selection and definition of appropriate measures for assessing the efficiency or effectiveness of processes and organizations (Costa and Formoso 2004). It should contain several key elements: (a) procedures for collecting and processing data; (b) timetables and protocols for distributing information about performance to users within and outside the organization; (c) a learning approach to identify what actions can be taken to further improve performance; and (d) a review process which ensures that the PM system is regularly updated (Neely et al. 1997). PM systems play a key role in business management, as it provides the necessary information for process control, enables the establishment of challenging and feasible goals, and facilitates communication between different managerial levels (Hall et al. 1991) Moreover, it helps to align efforts and resources to the most important aspects of the business (Lantelme and Formoso 2000) and produce data that can be used as a reference for process improvement (Pavlov and Bourne 2011).

Despite its importance, many problems concerned with measuring performance in construction projects have been pointed out in the literature, such as: (i) most companies use traditional lagging indicators that are focused on results making them ineffective to support timely decision making (Sarhan and Fox 2013); (ii) some PM systems contain too many measures, most of them linked to supporting rather than critical processes (Costa and Formoso 2004); (iii) the implementation of PM systems is limited to the selection of isolated measures, neglecting the necessary changes in decision-making (Beatham et al. 2004); and (iv) PM systems are not properly integrated to improvement initiatives (Kennerley and Neely 2003).

PM has an important role in the implementation of some Lean Production principles, such as reducing the share of non-value-adding activities (waste), increasing process transparency, building continuous improvement into the process, and benchmarking (Koskela 2000). However, the literature on PM for Lean Production Systems in the Construction Industry is relatively scarce. Very often, the implementation of Lean concepts and principles in production management is simply monitored by Last Planner related indicators (España et al. 2012; Sacks et al. 2017). There seem to be opportunities for extending PM systems in companies that have adopted the Lean Production Philosophy, especially by using some leading indicators related to core Lean and principles, such as pull production, WIP control, and continuous flow, for instance. In fact, despite the large number of Lean implementations reported in the literature, very little has been reported on the development of PM systems that are effective for assessing the impact of lean implementation (Sanchez and Pérez 2004). Besides, there is a lack of studies on how Lean companies (or projects) use indicators and to what extent these reflect the result of actions that have been undertaken (Bellisario and Pavlov 2018). By contrast, PM cannot be considered as an end in itself: it must be regarded as a support activity, not adding value directly to the product (Koskela 1992).

This paper presents preliminary results of a research study that aims to propose a set of requirements for PMS from a lean production perspective, and a taxonomy of metrics for 
lean production systems. It discusses the scope of the performance metrics adopted by five companies from South America involved in the implementation of Lean Production Systems. The scope of this investigation is limited to construction projects as production systems, rather than PM at the level of construction organizations.

\section{ROLE OF PM IN LEAN PRODUCTION SYSTEMS}

\section{REQUIREMENTS FOR PM SYSTEMS}

PM plays a different role in lean production systems when compared to traditional managerial systems (Maskell 1991). Traditional measures compare task completion, cost results, and quality data to the plan or budget (España et al. 2012). This is based on the thermostat model: controlling means returning to standard by correcting deviation, but not much effort is made in the identification and elimination of the root causes of those deviations (Koskela and Howell 2002).

Koskela (1992) makes some recommendations for the development of PM systems so that it supports the application of lean production concepts: investigate the causes of the problems, measure waste by assessing the share of non-value-adding activities, monitor variability, cycle time and defects, and promote continuous improvement (or learning). In summary, PM systems should be capable of evaluating the production system performance in relation to flow and value, in addition to transformation (traditionally monitored), in order to support decision making (España et al. 2012). Therefore, the definition of performance metrics in Lean Production Systems should address a set of requirements (adapted from MASKELL, 1991):

(i) Have a direct relation with the manufacturing strategy: there are two reasons to keep PM aligned with the company's manufacturing (or production) strategy. The first one is the need to assess whether the strategic goals are being achieved, and their achievement is directly linked to the actions taken (and measured) in production. The second reason refers to the translation of strategy through operational measures that prioritize what is most important to the company. In addition, (Bhasin 2008) points out the importance of establishing an effective system which translate the information gathered from PM to an effective strategy for action.

(ii) Use primarily nonfinancial measures: PM must be close to actions at the shop floor level by using metrics that shows what is most relevant. This provide reliable information about operational reality (Bellisario and Pavlov 2018). By contrast, financial measures are important for accounting controls and external reporting, but not for guiding the daily actions of production.

(iii) Create local control systems: indicators should be revised in order to meet the requirements of each situation (Koskela 1992). Lean manufacturing organizations continuously adapt their performance measures to suit their context, consequently stimulating debate and creating opportunities for learning (Bellisario and Pavlov 2018). Therefore, it is beneficial to provide some degree of freedom for the manager of each plant (or project) to adopt some indicators that meets their local needs. They will differ from one plant (or project) to another, being used for local control. The role of these indicators is to stimulate the involvement of operational teams in continuous improvement initiatives. 
(iv) Be flexible and change by time as needed: as continuous improvement play an important role in Lean implementation, a PM system must be able to keep pace with changes in the production system (Maskell 1991). External changes to the company may also require updating the indicator system (Kennerley and Neely 2003)

(v) Be simple and provide quick feedback to users: stakeholders should be able to understand the meaning and importance of the information provided. Metrics should be objective and simple. Moreover, PM systems must provide relevant, reliable and timely information (Neely et al. 1997). As information is clear and simple, deviation detection becomes faster, allowing decision-making and. actions to be performed in a short amount of time (Maskell 1991). This results in a form of feedback which better fits the needs of shop-floor employees and managers (Fullerton and Wempe 2009).

(vi) Promote improvement and learning by increasing process transparency: the results of PM must be made available to decision makers on-time and at the point of use. Besides supporting the early detection of problems, process transparency facilitate collaboration among team members (Ewenstein and Whyte 2007), mitigate problems related to the management of complex production systems (Viana 2015), and increase workforce motivation (Galsworth 1997). The choice of the metrics and the form of displaying them depend of the specific needs of each user (e.g. managers, workers, subcontractors, etc.). Bhasin (2008) also points out the importance of adopting information and communication technology to automate data collection and analysis and the production of reports, when possible.

\section{Taxonomy for PM in Lean Production Systems}

The use of two categories, result (or output) and process indicators, has already been widely discussed in the literature, and represents one of the key requirements for PM systems in general (Beatham et al. 2004). It means that PM must go beyond just indicating a result. It should have a more important role, aligned with lean principles; collaborative teams with a culture of responsibility; structured critical analysis and decision making; use of historical data; continuous learning and improvement; and effective communication (España et al. 2012). According to Karlsson and Åhlstrom (1996), the performance of Lean Production Systems can be analyzed by considering a set of factors (named groups of indicators): elimination of waste, continuous improvement, zero defects, just-in-time, and multifunctional teams. For each factor (or manufacturing objective), Karlsson and Åhlstrom (1996) identified the determinants that could reflect the changes in a company in the process to become lean, based on the concepts proposed by Womack, Jones, and Ross (1990). These determinants can be actions, principles or changes implemented in a company with the aim of improving performance. Sanchez and Pérez (2004) applied the model proposed by Karlsson and Åhlstrom (1996), by adapting to the context of services. Based on Karlsson and Åhlstrom (1996) and Sanchez and Pérez (2004), Rivera and Manotas (2014) adopted five factors (named dimensions) for PM, which are related to continuous improvement. Table 1 presents the factors adopted in those three research studies.

Rivera and Manotas (2014) proposes a set of 21 performance indicators for monitoring the implementation of lean practices, and points out that they must be integrated to continuous improvement initiatives. These authors proposed a taxonomy for metrics in terms 
of Focus and Scope. Focus is related to the way decision makers use them and can be divided in process focus and result focus. Scope is concerned with the way indicators are be monitored, collected and used, and can be divided in organizational and frequency scope.

\begin{tabular}{|l|l|}
\hline \multicolumn{1}{|c|}{ Karlsson and Åhlström (1996) } & \multicolumn{1}{|c|}{$\begin{array}{c}\text { Sánchez and Pérez (2004) and } \\
\text { Rivera and Manotas (2014) }\end{array}$} \\
\hline Elimination of waste & Elimination of waste \\
\hline Continuous improvement & Continuous improvement \\
\hline Zero defects & Continuous flow and Pull-driven systems \\
\hline Just In Time (JIT) & Multifunctional teams \\
\hline Pull instead of push (related to JIT) & \\
\hline Multifunctional teams (MT) & \\
\hline Decentralized responsibility (related to multifunctional teams) & - \\
\hline Integrated functions (related to MT) & Information systems \\
\hline Vertical Information Systems (related to MT) & \\
\hline
\end{tabular}

Table 1: Factors adopted for measuring performance of Lean Production Systems

\section{RESEARCH METHOD}

The research work described in this paper has a descriptive character, and corresponds to one of the early stages of the research project that aims to propose a set of requirements for PM in Lean Production Systems in the construction industry. The performance metrics of five construction companies from Latin America adopted for assessing the performance of production systems have been analyzed. Table 2Error! Reference source not found. presents the profile of the group of companies. These were selected for the following reasons: have a well-structured PM systems; have successfully implemented a number of lean production practices; provided access to information. The main sources of evidence adopted were: analysis of documents and visual devices, participant observation, and unstructured interviews with managers.

\begin{tabular}{|c|c|c|c|c|c|}
\hline & Company A & Company B & Company C & Company D & Company E \\
\hline $\begin{array}{l}\text { Company } \\
\text { size }\end{array}$ & Large & Large & Small-sized & Large & Large \\
\hline $\begin{array}{l}\text { Main } \\
\text { activities }\end{array}$ & $\begin{array}{c}\text { Construction and real } \\
\text { estate development } \\
\text { for middle and upper- } \\
\text { middle-class } \\
\text { residential markets }\end{array}$ & $\begin{array}{c}\text { Services and integrated } \\
\text { solutions in construction } \\
\text { for Industrial and offshore } \\
\text { works }\end{array}$ & $\begin{array}{c}\text { Construction and real } \\
\text { estate development } \\
\text { for middle and upper- } \\
\text { middle-class } \\
\text { residential markets }\end{array}$ & $\begin{array}{l}\text { Construction and real } \\
\text { estate development } \\
\text { for low, middle and } \\
\text { upper-middle-class } \\
\text { residential markets }\end{array}$ & $\begin{array}{l}\text { Development and } \\
\text { construction } \\
\text { buildings for private } \\
\text { clients (mostly } \\
\text { industrial projects) }\end{array}$ \\
\hline \begin{tabular}{|l|} 
Main \\
characte- \\
ristics
\end{tabular} & $\begin{array}{c}\text { Considered as a } \\
\text { benchmark in Lean } \\
\text { Construction, started } \\
\text { lean implementation } \\
\text { in the 90's }\end{array}$ & $\begin{array}{c}\text { Multinational Company } \\
\text { that have implemented } \\
\text { lean in complex projects } \\
\text { (e.g. offshore) }\end{array}$ & $\begin{array}{l}\text { Family owned } \\
\text { company, started a } \\
\text { Lean Journey less } \\
\text { than } 3 \text { years ago }\end{array}$ & $\begin{array}{c}\text { Started a Lean } \\
\text { journey Company } \\
\text { less than } 3 \text { years ago }\end{array}$ & $\begin{array}{c}\text { Works mostly as a } \\
\text { contractor, in a } \\
\text { wide range of } \\
\text { different projects. } \\
\text { Started its Lean } \\
\text { journey less than } 5 \\
\text { years ago }\end{array}$ \\
\hline $\begin{array}{l}\text { Main lean } \\
\text { practices } \\
\text { adopted }\end{array}$ & \begin{tabular}{|l} 
- \\
- Kast Planner \\
- $5 S$ \\
- Prototyping \\
- Visual management \\
- Standardized work
\end{tabular} & $\begin{array}{l}\text { - Last Planner } \\
\text { - Kanban } \\
\text { - Multi-function teams } \\
\text { - Visual management } \\
\text { - Standardized work } \\
\text { - Value Stream Mapping }\end{array}$ & $\begin{array}{l}\text { - Last Planner } \\
\text { - Visual management } \\
\text { - Task completion } \\
\text { control } \\
\text { - Takt-time planning }\end{array}$ & $\begin{array}{l}\text { - Last Planner } \\
\text { - Visual Management } \\
\text { - } 5 S \\
\text { - Task completion } \\
\text { Takt-time planning }\end{array}$ & $\begin{array}{l}\text { - Last Planner } \\
\text { - Visual } \\
\text { Management } \\
\text { - Takt-time } \\
\text { planning }\end{array}$ \\
\hline
\end{tabular}

Table 2: Description of the five companies

All five companies have kept a historical database of indicators, which is sometimes used for comparisons and decision-making. They have to some extend undertaken internal and external benchmarking exercises. 


\section{Performance Measures Used by the Companies}

This section describes the performance metrics related to the lean implementation that have been used by the group of five companies. All of them had other metrics, not reported in this paper, which are often linked to the traditional way of measuring performance, such as cost deviation, project delays, and project progress. Table 3 provides an overview of the metrics adopted by the five the companies.

\begin{tabular}{|c|c|c|c|c|c|}
\hline Indicators & Company A & Company B & Company C & Company D & Company E \\
\hline Last Planner Metrics & $\mathrm{x}$ & $\mathrm{x}$ & $\mathrm{x}$ & $\mathrm{x}$ & $\mathrm{x}$ \\
\hline Effectiveness of LPS Implementation & $\mathrm{x}$ & & $\mathrm{x}$ & $\mathrm{x}$ & \\
\hline Daily OTP (On Time Performance) & & $\mathrm{x}$ & & & \\
\hline Gemba Walk Wastes & & $\mathrm{x}$ & $\mathrm{x}$ & & \\
\hline Number of Kaizen Ideas & & $\mathrm{x}$ & & & \\
\hline Terminality and Anticipation & & & $\mathrm{x}$ & $\mathrm{x}$ & \\
\hline HeatMap & & & & $\mathrm{x}$ & \\
\hline Batch Adherence Control & & & & $\mathrm{x}$ & $\mathrm{x}$ \\
\hline Cycle Time & & & & $\mathrm{x}$ & $\mathrm{x}$ \\
\hline Rhythm Deviation & $\mathrm{x}$ & & $\mathrm{x}$ & $\mathrm{x}$ & $\mathrm{x}$ \\
\hline
\end{tabular}

Table 3: Indicators supporting lean practices identified in the companies studied.

\section{Last Planner Metrics}

All companies had implemented Last Planner System (LPS), and adopted the metrics that are often used at the look-ahead and weekly planning level: overall PPC (Percentage of Plan Completed), PPC for different crews or subcontractors; Causes for the noncompletion of work packages; Overall number of constraints identified (NCI); Percentage of Constraints Removed (PCR); and Relative number of constraint for each category.

\section{Effectiveness of LPS Implementation}

Three of the companies used a metric that assess the degree of implementation of planning and control practices. It is based on a checklist of 15 practices, that was originally proposed by Bernardes and Formoso ${ }^{4}$. This checklist covers the tree planning horizons and allows the evaluation of the degree of maturity of planning systems. None of the companies used maturity models for doing a broad assessment of Lean implementation beyond LPS.

\section{Daily OTP (On Time Performance).}

Daily OTP indicator monitors the percentage of the daily tasks that is completed, in relation to the number of tasks planned through the cards in the PPM Board ${ }^{5}$ for each project or supervisor. This metric is similar to the PPC indicator (calculated daily) but is extracted from the visual management panel of each project (PPM Board). Deviations between planned and executed activities are calculated and presented in a visual device. The Weekly OTP indicator is an overview of the performance over a four week period, and provides some details from the

${ }^{4}$ Bernardes, Maurício, and Formoso, Carlos. 2002. "Contributions To the Evaluation of Production Planning and Control Systems in Building Companies." IProc. of the Ann. Conf. of Int'l Group for Lean Construction, 10., 2002, Gramado: 1-11.

${ }^{5}$ Daily planning panel, similar to a Heijunka Box. Visual tool for a daily scheduling of execution and prefabrication; based on Takt time on a daily basis and commitment plan (Last Planner System). 
current week (e.g. progress of work by team, supervisor and area). Data comes from Daily Performance Sheets (Daily OTP). Correction and prevention actions are proposed in response to deviations pointed out by this indicator. These are defined and recorded in A3 reports. This indicator can also be used for monitoring deviations in relation to the Takt Time on a daily basis, process efficiency and utilization of capacity, especially regarding bottleneck resources.

\section{Gemba Walk Waste}

The aim of the Gemba Walk is to identify waste (non-value-adding activities) in different processes in the construction site. This measure is carried out on a regular basis to ensure the continuous identification and removal of waste, based on previous Gemba walk. It typically undertaken every two weeks, and involves both top managers and site managers. During the Gemba walk, it is essential to observe how the process is carried out in the work area, as well as to speak to workers who are performing the job, so as to ensure the process is fully understood. While conducting the Gemba walk, one should identify the different types of waste at different work stations, follow the material and information flows and look out for possible wastes. Some waste categories can be used, such as the Seven Wastes by Ohno (1988) ${ }^{6}$, underutilization of labor, and energy waste.

\section{Number of Kaizen Ideas}

This indicator is based on the improvement initiatives coming from that were put into practice. Each idea is evaluated by a lean team, that authorizes or not its application in other projects. The metric is calculated in a monthly basis (number of kaizens applied per month). This indicator can be used for giving awards to individual employees or groups of employees whose idea results in the best improvement (e.g. reduction in the number of man-hours or non value adding time). Sometimes the proportion of top-down and bottom-up kaizen ideas is also calculated, i.e. the ratio between the number of kaizens ideas originated in the shop floor and the number of kaizens ideas coming from top managers, senior managers and directors.

\section{Terminality and Anticipation}

According to Koskela (2004), the beginning of an activity should consider the concept of "complete kit" (Ronen 1992). When this not occurs, there is a reduction of performance in terms of efficiency and quality, named making-do, which may cause other types of waste, such as: increase in the share of non-value-adding activities; increase in work in progress (WIP); increase in cycle time; rework; lack of safety; and unfinished work. De Vargas (2018) ${ }^{7}$ proposed metrics related to those wastes: percentage of completed packages with terminality and percentage of anticipated tasks. These indicators are generated from a matrix that relates activities (columns) to production units (rows). Each cell presents information of task status, whether it is in progress; stopped; or not released (not started). In the case of stoppage, a cause must be reported. The indicator Percentage of Anticipated Tasks is the ratio between anticipated and non-anticipated tasks. The terminality indicator is calculated by the percentage of tasks that started, but were not completed. The third indicators is concerned with the causes that prevented task from

${ }^{6}$ Ohno, Taiichi. The Toyota Production System: Beyond Large-Scale Production. Portland, Oregon: Productivity Press, 1988.

${ }^{7}$ De Vargas, F. B. (2018). "Método para Planejamento e Controle da Produção baseado em Zonas de Trabalho e BIM.” Dissertação (Mestrado em Engenharia Civil) - PPGCI, Porto Alegre. 
accomplishment. Besides, the matrix itself provides a visual map of project status and information for monitoring cycle time. Figure 1 shows an example of the matrix.

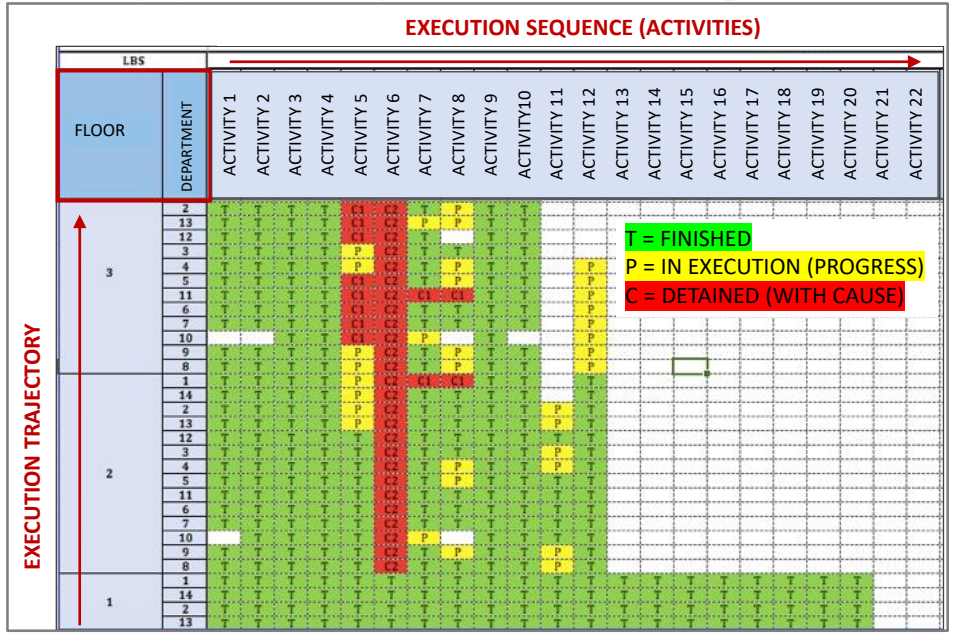

Figure 1: Examples of the chart for anticipation and terminality control.

\section{Heatmap}

Heatmaps are visual representations of colors that show how the workers are distributed along production units shows an example. It helps to control the number of people working in each floor, apartment or batch. When combined with the terminality indicator it provides a better overview of project progress for decision making. When workers are scattered in a construction site, a larger team is needed to keep track of the execution of the tasks. In this scenario, the occurrence of low quality, re-work, WIP, and informal work is usual.

\section{Batch Adherence Control}

The Batch adherence indicator shows the adherence of the tasks executed or planned at the lookahead level, considering a Location Based System. It is the ratio between the number of batches (or sub-stages) performed by the number of batches (sub-stages) planned for the period. Viana (2015) pointed out that the use of metrics concerned with batch adherence can contribute to the reduction of work-inprogress. Figure 3

shows an example of this type of control. It shows the trend of starting new work packages (new batches) without the completion of the previous ones, increasing generating WIP.

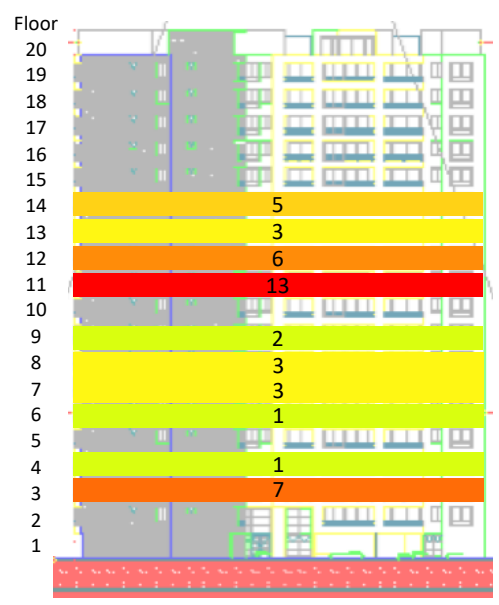

Figure 2: Example of Heatmap. 


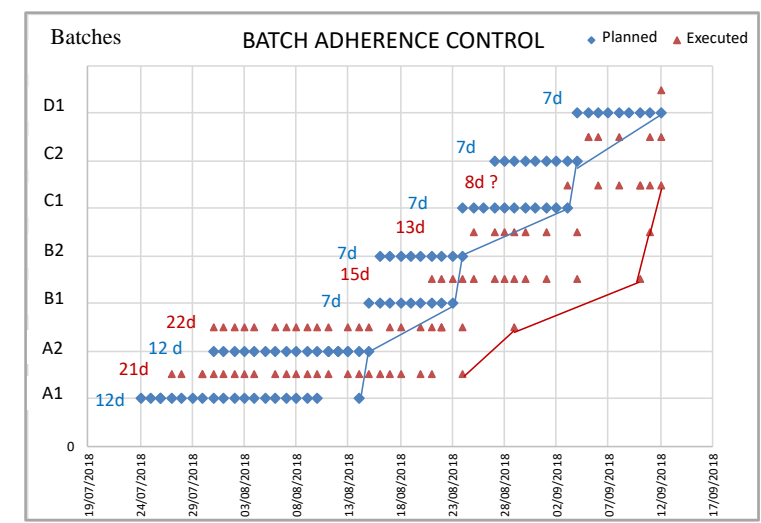

Figure 3: Example of a chart to monitor batch adherence.

\section{Cycle Time}

According to Rother and Shook (1998) cycle time refers to how often a part or product is completed by a process, including processing time, storage, inspection and rework. In a project with repetition in the production base units (or production batches) it is important to monitor the cycle time for the execution of each batch. The goal is to extract cycle time information from each batch/activity for monitoring its variance and promoting optimization. It generates alerts for the planning process on a pull system. Monitoring cycle time variance may leads to increased productivity and faster delivery to the customer (Ballard 2001); waste elimination, faster cycles of deviation detection and correction (Koskela 1992).

\section{Deviation of Rhythm}

Rhythm control represents a form of critical process control that incorporates lean concepts, whereas only fully accomplished tasks (batches) are considered. Each team must complete their work in a specified batch in a certain amount of time, also called takt time (Frandson et al. 2015). The indicator encourages the entire team, including subcontractors, to focus their work on completing the lot (with terminality). Figure 4 shows the impact that critical tasks have on other activities. Since most of this activities are critical for production, a change in one line (or activity) needs to be monitored and the others should to be evaluated for any interference.

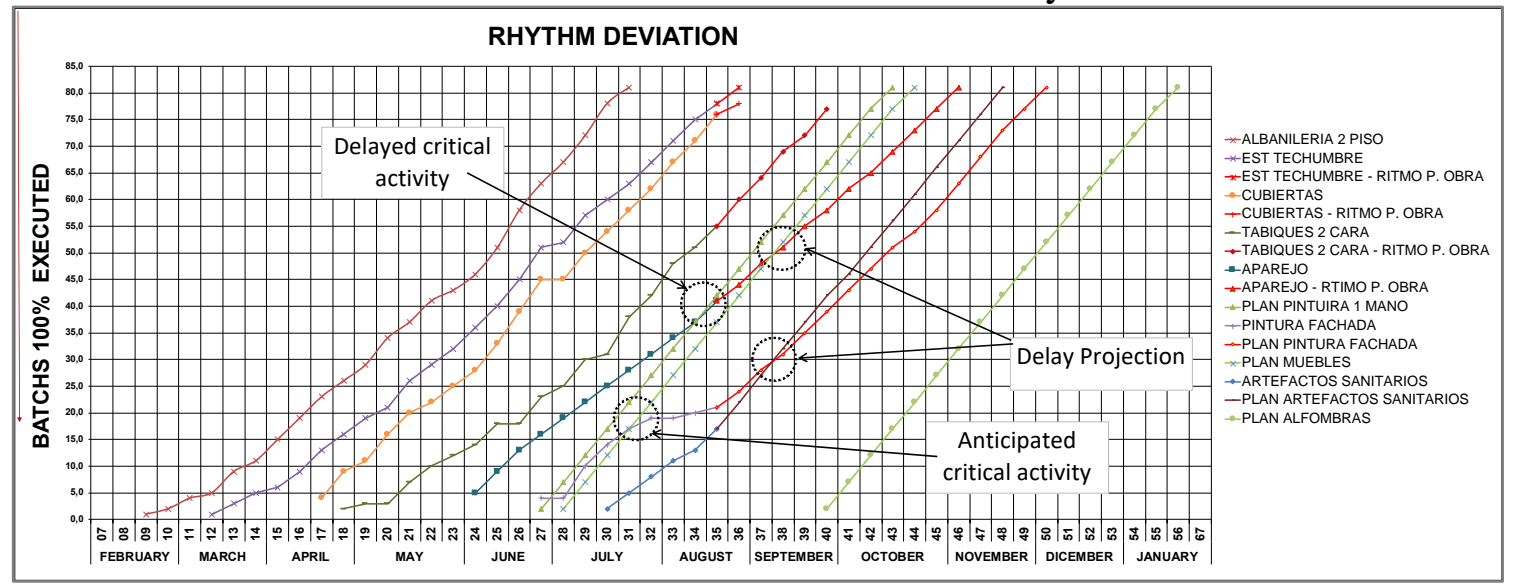

Figure 4: Example of a chart to monitor the rhythm of different processes. 


\section{DISCUSSION}

A preliminary assessment of the degree of adoption of the requirements for performance metrics identified in the literature was made for the five companies. Three different grades have been used in this assessment, based on the perception of the research team: totally adopted $(\mathrm{T})$, partially adopted $(\mathrm{P})$, and not adopted $(\mathrm{N})$. Figure 5 presents this results for each of those companies. Companies A and B can be considered as the most advanced ones in terms of PM. Moreover, most companies were effective in terms of implementing quick feedback to users and process transparency. The least considered requirement was create local control systems and none of the companies have fully adopted that requirement.

\begin{tabular}{|l|c|c|c|c|c|}
\hline \multicolumn{1}{|c|}{ Requirements } & Company A & Company B & Company C & Company D & Company E \\
\hline Have a direct relation with manufacturing strategy & $\mathrm{P}$ & $\mathrm{T}$ & $\mathrm{P}$ & $\mathrm{P}$ & $\mathrm{P}$ \\
\hline Use primarily nonfinancial measures & $\mathrm{T}$ & $\mathrm{T}$ & $\mathrm{P}$ & $\mathrm{T}$ & $\mathrm{P}$ \\
\hline Create local control systems & $\mathrm{P}$ & $\mathrm{P}$ & $\mathrm{N}$ & $\mathrm{N}$ & $\mathrm{P}$ \\
\hline Be flexible and change by time as needed & $\mathrm{T}$ & $\mathrm{P}$ & $\mathrm{P}$ & $\mathrm{N}$ & $\mathrm{N}$ \\
\hline Be simple and provide quick feedback to users & $\mathrm{T}$ & $\mathrm{T}$ & $\mathrm{T}$ & $\mathrm{T}$ & $\mathrm{T}$ \\
\hline $\begin{array}{l}\text { Promote improvement and learning by increasing } \\
\text { process transparency }\end{array}$ & $\mathrm{T}$ & $\mathrm{T}$ & $\mathrm{P}$ & $\mathrm{T}$ & $\mathrm{P}$ \\
\hline
\end{tabular}

Figure 5: Adoption of requirements for the design of PM systems

Table 4ERROR! REFERENCE SOURCE NOT FOUND. presents the classification of the metrics adopted by the group of companies according to a set of lean principles. This is an initial analysis based on the taxonomies proposed in the literature. Further work is necessary to refine this taxonomy, considering the context of the construction industry. It is worth mentioning that none of the companies emphasize in their control systems metrics related to zero defects and multifunctional teams.

\begin{tabular}{|l|l|}
\hline \multicolumn{1}{|c|}{ Lean Principles } & \multicolumn{1}{c|}{ Indicators aligned to lean principles } \\
\hline Elimination of waste & Gemba Walk Wastes \\
\hline Continuous improvement & $\begin{array}{l}\text { Number of Kaizen Ideas } \\
\text { Top-down and Bottom-up Kaizen Ideas Proportion }\end{array}$ \\
\hline Just In Time (JIT) & HeatMap \\
\hline \multirow{2}{*}{ Pull instead of push } & $\begin{array}{l}\text { Last Planner Measures } \\
\text { Effectiveness LPS Implementation } \\
\text { Daily OTP }\end{array}$ \\
\hline \multirow{2}{*}{ Continuous flow } & $\begin{array}{l}\text { Terminality and Anticipation } \\
\text { Batch Adherence Control } \\
\text { Cycle Time }\end{array}$ \\
\hline Takt time planning & Rhythm Deviation \\
\hline
\end{tabular}

Table 4: Indicators and corresponding Lean Principle

\section{FINAL COMMENTS}

This paper has presented some preliminary results of an investigation on the requirements and taxonomies for PM systems for lean production systems. The main lean metrics adopted by five companies from South America have been briefly presented and assessed, considering the requirements and taxonomies that have been proposed in the literature. In the future, additional metrics could be suggested for monitoring other aspects of lean implementation, such as waste reduction (e.g. work sampling technique, inventory level), pull production, and supply chain integration. Also further work is necessary to refine the set of requirements, considering PM systems as a whole, rather that only the design of the metrics. Moreover, none of the taxonomies proposed in the literature for performance 
metrics are directly applicable to the construction industry, and future work concerned with taxonomies applicable to lean production systems in the construction industry is needed.

\section{REFERENCES}

Ballard, G. (2001). "Cycle time reduction in home building." 9th annual conference of the International Group for Lean Construction, 1-10.

Bassioni, H. A., Hassan, T. M., and Price, A. D. F. (2008). "Evaluation and analysis of criteria and sub-criteria of a construction excellence model." Engineering, Construction and Architectural Management, 15(1), 21-41.

Beatham, S., Anumba, C., Thorpe, T., and Hedges, I. (2004). "KPIs: A critical appraisal of their use in construction." Benchmarking: An International Journal, 11(1), 93-117.

Bellisario, A., and Pavlov, A. (2018). "Performance management practices in lean manufacturing organizations: a systematic review of research evidence." Production Planning \& Control, Taylor \& Francis, 29(5), 367-385.

Bhasin, S. (2008). "Lean and performance measurement." Journal of Manufacturing Technology Management, 19(5), 670-684.

Costa, D. B., and Formoso, C. T. (2004). "A set of evaluation criteria for performance measurement systems in the construction industry." Journal of Financial Management of Property and Construction, 9(2), 91-101.

Costa, D. B., Formoso, C. T., Kagioglou, M., and Alarcon, L. F. (2006). "Benchmarking Initiatives in the Construction Industry: Lessons Learned and Improvement Opportunities." Journal of Management in Engineering, 22(4).

España, F., Tsao, C. C. Y., and Houser, M. (2012). "Driving Continuous Improvement By Developing and Leveraging Lean Key Performance Indicators." 20th Conference of the International Group for Lean Construction.

Ewenstein, B., and Whyte, J. K. (2007). "Visual representations as 'artefacts of knowing.", Building Research \& Information, 35(1), 81-89.

Frandson, A. G., Seppänen, O., and Tommelein, I. D. (2015). "Comparison Between Location Based Management and Takt Time Planning." In: Proc. 23rd Ann. Conf. of the Int'l. Group for Lean Construction, 28-31 July, Perth, Australia, 3-12.

Fullerton, R. R., and Wempe, W. F. (2009). "Lean manufacturing, non-financial performance measures, and financial performance." International Journal of Operations and Production Management, 29(3), 214-240.

Galsworth, G. (1997). Visual systems: harnessing the power of the visual workplace. American Management Association, New York.

Hall, R. W., Johnson, H. T., and Turney, P. B. B. (1991). Measuring up : charting pathways to manufacturing excellence. Business One Irwin, Homewood, Illinois, USA.

Kagioglou, M., Cooper, R., and Aouad, G. (2001). "Performance Management in Construction: a Conceptual Framework." Construction Management and Economics, 19(1), 85-95.

Karlsson, C., and Åhlstrom, P. (1996). "Assessing changes towards lean production." International Journal of Operations \& Production Management, 16(2), 24-41.

Kennerley,M., and Neely,A.(2003). "Measuring performance in a changing business environment." International Journal of Operations and Production Management, 23(2), 213-229. 
Koskela, L. (1992). "Application of the new production philosophy to construction." Standford Univeristy, Center for Integrated Facility Engineering, Technical Report, 1-81.

Koskela, L. (2000). "An exploration towards a production theory and its application to construction." VTT Publications, Technical Research Centre of Finland.

Koskela, L. (2004). "Making Do - The Eight Category of Waste." Proc. of the 12th Ann. Conf. of Int'l Group for Lean Construction, Denmark.

Koskela, L., and Howell, G. (2002). "The underlying theory of project management is obsolate." Proceedings of the PMI Research Conference, 293-302.

Lantelme, E., and Formoso, C. T. (2000). "Improving Performance Through Measurement: The Application of Lean Production and Organisational Learning Principles." International Conference of the International Group for Lean Construction.

Love, P. E. D., and Holt, G. D. (2000). "Construction business performance measurement: the SPM alternative." Business Process Management Journal, 6(5), 408-416.

Maskell, B. H. (1991). Performance measurement for world class manufacturing: Productivity Press, Portland, OR.

Neely, A., Richards, H., Mills, J., Platts, K., and Bourne, M. (1997). "Designing performance measures: a structured approach." International Journal of Operations \& Production Management, 17(11), 1131-1152.

Pavlov, A., and Bourne, M. (2011). "Explaining the effects of performance measurement on performance: An organizational routines perspective." International Journal of Operations and Production Management, 31(1), 101-122.

Rivera, L., and Manotas, D. F. (2014). "Performance Measurement in Lean Manufacturing Environments." Lean Manufacturing in the Developing World, 445-460.

Robinson, H. S., Anumba, C. J., Carrillo, P. M., and Al-Ghassani, A. . (2005). "Business performance measurement practices in construction engineering organisations." Measuring Business Excellence, 9(1), 13-22.

Ronen, B. (1992). "The complete kit concept." International Journal of Production Research, 30(10), 2457-2466.

Rother, M., and Shook, J. (1998). Learning to See: Value stream mapping to create value and eliminate muda.

Sacks, R., Seppänen, O., Priven, V., and Savosnick, J. (2017). "Construction flow index: a metric of production flow quality in construction." Construction Management and Economics, Routledge, 35(1-2), 45-63.

Sanchez, A. M., and Pérez, M. P. (2004). "The use of lean indicators for operations management in services." International Journal of Services Technology and Management, 5(5/6), 465.

Sarhan, S., and Fox, A. (2013). "Performance measurement in the UK construction industry and its role in supporting the application of lean construction concepts." Australasian Journal of Construction Economics and Building, 13(1), 23-35.

Viana, D. D. (2015). "Integrated production planning and control model for engineer-to-order prefabricated building systems.” Ph. D. Federal University of Rio Grande do Sul, Porto Alegre.

Waggoner, D. B., Neely, A., and Kennerley, M. (1999). "The forces that shape organisational performance measurement systems:" International Journal of Production Economics, 60-61, 53-60. 
Performance Measurement in Lean Production Systems: an Exploration on Requirements and Taxonomies

Womack, J. P., Jones, D. T., and Ross, D. (1990). The Machine that Changed the World. Rawson Associates, New York, NY.

Yu, I., Kim, K., Asce, A. M., Jung, Y., Asce, A. M., Chin, S., and Asce, M. (2007). "Cost contingency management (2007).” Journal of Management in Engineering, 23(3), 131-139. 